
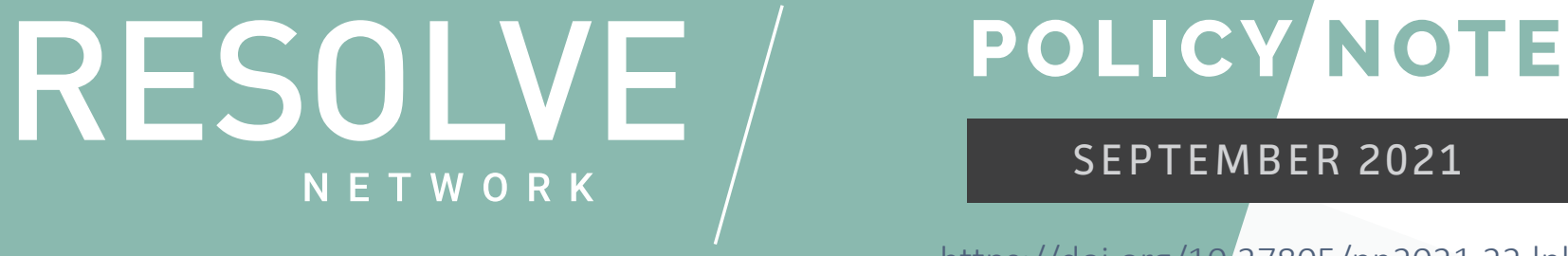

https://doi.org/10.37805/pn2021.22.Ipbi

\title{
PEACE (RE)BUILDING INITIATIVES: INSIGHTS FROM SOUTHERN KADUNA, NIGERIA
}

\author{
BENJAMIN MAIANGWA
}

LEARNING FROM LOCAL

PEACEBUILDING APPROACHES

\section{${ }^{6}$ Oftentimes in the context of severe suffering brought about by}

conflicts, people rely on their socio-cultural resources to survive and

rebuild from the disharmony and ruins in their communities."

\section{FAST FACTS Context}

$\rightarrow$ Conflicting groups in Kaduna are contesting the terms of belonging and attachment to state-level politics.

$\rightarrow$ Peaceful inter-ethnic and inter-religious co-existence depends on how well these groups can negotiate complex adversarial identities.

$\rightarrow$ Such negotiations can be achieved in established community centers for constructive dialogue, mediation, vocational projects, and storytelling.

$\rightarrow$ An information database on incidents of kidnapping that identifies perpetrators and their relationship to state-level conflict drivers together with a media channel for engaging local peacebuilders could constitute a critical conflict warning system in Kaduna.
Kaduna State "straddles Nigeria's ethnic and religious divide." ${ }^{1}$ Its Christian and Muslim populations are almost evenly split, occupying the northern and southern parts of the state, respectively. There is also a considerable population of both communities in the two regions. The numerous Christian groups represent more than 40 different ethnic communities. The composition of these groups varies according to their size and number. Some of the most visible groups include the Bajju, Adara, Bakulu, Takad, Atyap, Oegworok, Ham, Moroa, Ninkyob, Tsam, Sholio, Kuvori, Anghan, and a few others with whom they share similar heritage and language. ${ }^{2}$ These

1 Eric Guttschuss, 'Leave Everything to God.' Accountability for Intercommunal Violence in Plateau and Kaduna States, Nigeria (USA: Human Rights Watch, 2013), https://reliefweb.int/sites/reliefweb.int/files/ resources/nigeria1213 ForUpload.pdf.

2 Philip Hayab John, "Narratives of identity and sociocultural worldview in song texts of the Ham of Nigeria: A discourse analysis investigation," (PhD dissertation, Stellenbosch University, 2017), http://scholar. sun.ac.za/handle/10019.1/100914. 
groups generally refer to themselves as the people of Southern Kaduna. They also identify with the "Middle Belt" communities, a larger collection of (mostly Christian) political minorities who live across central Nigeria. Although the groups are predominantly the minority in terms of state political power dynamics, they "retain significant political power and hold key government posts." 3 The Fulani is also a heterogenous group with more than twenty categories that mostly identify as Fulbe or Pullo in singular. ${ }^{4}$ The complexities of these groups are telling of the fluidity and social constructions of identity.

In recent times, violent conflicts between the Fulani and the Southern Kaduna groups have devastated several communities in the area such as Sanga, Jema'a, Kaura, Bajju, Atyap, and Adara Chiefdoms. These conflicts have instilled a climate of fear evidenced by a disruption of traditional income-generating activities: many communities have been reluctant to cultivate their farmlands or engage in intergroup business transactions for fear of physical attack. Compounding issues is the perception of the government's lack of political will or readiness to contain the violence. Abdul Rauf Mustapha claims that "the federal government under President Buhari...has not been as forthright and energetic in addressing the repeated violence as might be expected." ${ }^{5}$ This perception is especially apt with regards to the rapid increase in abduction cases, which are often blamed on "unknown gunmen," a euphemism for what many in Nigeria have concluded are "killer-herdsmen." The reality, as Mustapha argues, is that the culprits are often "idle young male... within the pastoral communities" and other Nigerian ethnic groups who joined the kidnapping and rustling syndicates to form the "core constituency of the New Fringe Pastoralism." ${ }^{6}$

The ongoing conflicts in Kaduna are based in an inability to access and exert power, manifested through contested identity claims and attachments to territories by the Fulani and the Southern Kaduna groups. These competing claims are shaped not only by the pre-colonial context (Zazzau emirate slave-raiding and regional hegemony in Southern Kaduna), but also by British administrative choices (Hausa and Fulani proxy rule) that eventually became entrenched in partisan politics during the pre- and post-independence eras. ${ }^{7}$ The vestiges of these colonial policies were reinforced in the run-up to the 2019 gubernatorial elections, when the Governor (a Muslim) appointed a deputy who was also Muslim. This political decision ignited some apprehension within the quarters of the Christian ethnic groups. In short, these top-level political tensions over who governs in Kaduna State, or Nigeria, bleed into communal conflicts over farmland, grazing, and electoral outcomes.

\section{Relevance to policy and practice}

A central theme of the conflicts between these groups is the issue of identity, tied to their

3 Guttschuss, 'Leave Everything to God.'

4 Participants of the author's peacebuilding action research project conducted in Kaduna State between 2016 and 2019 ; Andrew Walker, "Eat the heart of the infidel": The harrowing of Nigeria and the rise of Boko Haram (London: Hurst \& Company, 2016).

5 Abdul Raufu Mustapha, "Introduction: Religious encounters in northern Nigeria," in Creed and Grievance: Muslim-Christian Relations and Conflict Resolution in Northern Nigeria, eds. Abdul Raufu Mustapha and David Ehrhardt (New York: James Currey, 2018), 15, https://doi.org/10.1017/9781787442375.

6 Abdul Raufu Mustapha, "Introduction: Religious encounters in northern Nigeria," 17.

7 Moses Ochonu, Colonialism by Proxy: Hausa Imperial Agents and Middle Belt Consciousness in Nigeria (Indiana: University of Indiana Press, 2014). 
connection to the land as either indigenous (those born in the area or have lived there for a long time) or autochthonous people (the acclaimed sons and daughters of the soil). Both concepts are primarily connected to the Anglophone and Francophone colonial arrangements of distinguishing groups based on natives vs. non-natives, citizens/indigenes vs. settlers binaries. ${ }^{8}$ This distinction was crucial for the colonial "divide (or define) and conquer" strategy. ${ }^{9}$ This policy endowed the socio-political landscape in the postcolony with a nervousness of belonging hinged on "tribalism."

In contemporary times, groups in Nigeria have continued to immortalize this identity distinction in their socio-political relations as they fear becoming nonentities in places they consider their home. It is for this fear, and perceptions of historical injustice and the lethargic response that violent crime has received in Nigeria, that groups with different ethnoreligious affiliation to the President believe that the government under the presidency of Muhammadu Buhari (who is Fulani and Muslim) is surrendering their land to the Fulani in the form of grazing reserves through policies such as the National Livestock Transformation Plan (NLTP).

The NLTP was designed to contain the perennial disturbances between farmers and herders, particularly the destruction of crops by cattle belonging to the Fulani. Given the lack of trust in the government and the overbearing impacts of violent attacks in the region, many Nigerians believed that the NLTP and other related federal proposals were meant as a subterfuge for "Islamization." This suspicion derives from historical perception and reality of the 1804 jihad and the subsequent establishment of the Caliphate in Sokoto which led to the political and cultural othering of other religious and ethnic groups from the 19th century onwards. Abdul Raufu Mustapha has argued that "the fear-real or imagined-of 'Islamization' is a common thread that runs through Christian narratives of their encounter with Muslims in northern Nigeria." ${ }^{10}$ For their part, the Fulani in Southern Kaduna also consider the area their home on the basis of their birth and long-term residency. This reality forms the nucleus of the crisis of belonging ${ }^{11}$ which is stirred by political grandstanding, opportunism, and effective polarization.

While narratives of intercommunal life in the state have often been acrimonious, the focus of this policy note is to bring the largely absent-or subjugated-peacebuilding activities of the people into perspectives for policymakers and peace practitioners. Crucially, peoples' cultures of peace in Kaduna underscore the acceptability of all sides of the need to proscribe open grazing, establish ranches for pastoralist groups, and create or consolidate the activities of existing local centers for constructive dialogue, ritual healing, and storytelling.

The findings of this note are drawn from a peacebuilding action research project conducted by the author in Kaduna State between 2016 and 2019. There were fifty participants altogether, which included local chiefs, clerics, development practitioners, teachers, civil servants, politicians, and members of the Miyetti Allah Cattle Breeders' Association of Nigeria (MACBAN) and the Southern Kaduna Peoples Union (SOKAPU).

\footnotetext{
8 Benjamin Maiangwa, The Crisis of Belonging and Ethnographies of Peacebuilding in Kaduna State, Nigeria (Lanham: Lexington Books, 2020).

9 Mahmood Mamdani, Neither Settler nor Native: The Making and Unmaking of Permanent Minorities (Cambridge, MA: Belknap Press, 2020).

10 Abdul Raufu Mustapha, "Introduction: Religious encounters in northern Nigeria."

11 Maiangwa, The Crisis of Belonging.
} 


\section{Recommendations}

The field of Peace and Conflict Studies (PACS) uses critical and decolonial methods and practices to advance local agency during and after conflicts. ${ }^{12}$ PACS considers conflict-affected communities as a repository of transformative ideas. People who experience violence and other oppressive realities are conscientious agents of change. Oftentimes in the context of severe suffering brought about by conflicts, these people rely on their socio-cultural resources to survive and rebuild from the disharmony and ruins in their communities. In some cases, the absence of the state's structures of law and order could impel conflict-affected people to seek other means of security ${ }^{13}$ and wellbeing, some of which could be constructive or destructive. This policy note documents and explores people's everyday practices of peace in Southern Kaduna both in the context and aftermaths of conflicts. It does this in a thematic format that draws out relevant recommendations for peacebuilders and policymakers.

\section{Healing through shared identities}

The long-lasting conflict in Southern Kaduna is intimately tied to the forging and sustaining of adversarial identities which feed off a mutual othering that only seeks victory over other identities. Unsurprisingly, characteristics that are central to one's identity, such as ethnicity, language, or religion, are weaponized to justify the inadequateness of the other and the violence that ought to be sanctioned against them. Any odds of peacebuilding will remain low so long as communities in Southern Kaduna see themselves as "tribalized" adversaries and not as members of a shared identity who should engage their differences in a dignified manner to form constructive relationships at various levels. Some avenues of fostering shared identities are presented below.

$\rightarrow$ Shared rituals. The people of Southern Kaduna invoke the intervention of God in periods of immense adversity. This practice was underscored in Anghan and Bakulu Chiefdoms which, to paraphrase Annika Björkdahl and Stefanie Kappler, ${ }^{14}$ are an island of relative peace in an otherwise troubled neighborhood. The people believed that part of the reasons for the relative calm in those chiefdoms owed to the astuteness of their chiefs, their magnanimity, and devout spirituality. They noted the potency of an oath ritual that they can participate in regardless of their different identities. This ritual entails a gathering in the Chief's premises to invoke the protection of God against bloodshed in their land. One chief shared his experience of the potency of such a ritual to build a shared identity and deter violence:

I called a meeting of the Ardos [the Fulani clan heads] and all the Fulani. We were just discussing and finding ways out, then without my prompting, one of them said "as far as we are concerned, we do not want anything to touch this land, and it will be attributed to Fulani. So, we are going to go on an oath. We

12 Sean Byrne, Mary Anne Clarke, and Aziz Rahman, "Colonialism and Peace and Conflict Studies," Peace and Conflict Studies 25, no. 1 (2018): Article 1, https://doi.org/10.46743/1082-7307/2018.1432.

13 Roger Mac Ginty, International Peacebuilding and Local Resistance: Hybrid Forms of Peace (New York: Palgrave Macmillan, 2011).

14 Annika Björkdahl and Stefanie Kappler, Peacebuilding and Spatial Transformation: Peace, Space, Peace (Abingdon, Oxon: Routledge. 2017). 
will take an oath that will be binding on all of us. Any Fulani man that is found bringing trouble or being part of any trouble, a curse will follow him." I said okay, and they chose an elderly man who made the proclamations on their behalf. I said we may be doing this here as if it is among people but know that God is a witness. Therefore, let us keep it and watch it.

While this form of everyday indicator of peace ${ }^{15}$ may not be a compelling mechanism for conflict deterrence, the people I interviewed claimed that it indicates the love they have for the land, their readiness to preserve and defend it, and their commitment to a higher force that they cannot control. As protection from God has been invoked, any interpretation of event can no longer be informed only by a rational approach. This ritual therefore positions the community as part of a spiritual realm and not only at the mercy of fellow humans. The belief in the comeuppance of God upon whomever might breach that ritual organically results from this reconfiguration of individuals as part of both a physical and spiritual plane.

The potential issue with such a spiritual disposition to "leave everything to God"16 is that in the context of continued state apathy/complicity in conflicts and strife people may resort to extreme measures to protect themselves as they become disenchanted with the state and do not identify the actions of God. Therefore, it might prove useful to complement this healing ritual with other non-criminalization outlets, also informed by that shared spirituality such as a community-led forum for truth and reconciliation. This forum could be organized in established community centers in collaboration with spiritual guides well-versed in these rituals.

Joint conversations, prayers, and reflections among different groups could physically take place on either a neutral ground or a ground with spiritual relevance for all parties involved. It will provide the platform for people to listen to each other and take responsibility for actions that might be upsetting the peace in the land. Such a process should be voluntary and conducted with the understanding that each community or group is now familiar with the trauma prism of simultaneously being a survivor, a perpetrator of sorts, a rescuer of others in difficult circumstances, and an agent of one's own healing.

$\rightarrow$ The moral code of Pulaaku. As dynamics of othering have become too familiar, a new social contract that builds on similarities and shared identities needs to be negotiated. Rather than focusing on characteristics and traits that have led to division and conflicts, focusing on characteristics that have traditionally been associated to positive connotations could be an option. One of such traditions is Pulaaku. According to the participants, Pulaaku embodies the essence of a bonafide Fulani person. It is the ontological personhood of a Fulani. Pulaaku finds expression in daily acts of privacy, piety, and respect. To live by way of Pulaaku is to be at peace with oneself and others, further reinforcing the positioning of one as being part of a whole that is broader than the individual. Some participants expressed the perception that Pulaaku has lost its prowess as a moral code, particularly among young people who seem oblivious to or detached from its virtues. They recommended the revival of the forgotten or dormant virtues of Pulaaku by educating their young people to abhor violence and appreciate

15 Pamina Firchow, Reclaiming Everyday Peace: Local Voices in Measurement and Evaluation after War (Cambridge: Cambridge University Press, 2018).

Guttschuss, 'Leave Everything to God.' 
the history of positive encounter between the different groups forged by their forbears.

While there is no real evidence that reviving the ontological primacy of Pulaaku would improve intergroup relations in southern Kaduna, what must be noted is its apparent impact on social relations. One MACBAN member claimed that a potent way to initiate dialogue is to invite a Fulani person to exercise Pulaaku. In doing so, Pulaaku could function as a catalyst for peace talks between the Fulani and other communities, if its relevance for such a conciliatory exercise is ascertained. Ironically, despite Pulaaku being indigenous to this region, this moral code might be foreign-in principle and practice - to many individuals. As such, it might not be enough to reintroduce this approach to one's behavior and social interactions without incentives. Discussion around what those incentives ought to be must involve people familiar with Pulaaku either because they were brought up in a household where those values were central or because they have a deep understanding of what abiding by Pulaaku involves.

Rewards could be conceptualized in terms of social capital and the support that one can expect from and provide to others on the premise of Pulaaku. This might particularly be relevant if trust toward the state is low, and communities must define rules that will favor their survival when facing upheaval. Pulaaku and associated rewards could be re-introduced to different segments of the populations and tailored to the unique leverages that positively influence one's social interactions and behavior. Pulaaku could be reintroduced and mobilized in schools, at home, in community gatherings, and in informal and formal employments. There might also be a need to undertake a form of disciplinary actions against those who contradict the values of Pulaaku to ensure compliance. Such actions, among others, may include attending regular classes on Pulaaku under the tutelage of the Fulani Ardos (chiefs) and other custodians of the culture such as the elders.

$\rightarrow$ Rethinking community, individualism, and masculinities. Seeking to rekindle shared identities begets a new approach to community, with a particular focus on the alignment between individuals' wellbeing and the community's wellbeing. The torturous relation that people have with the state might provide a fertile ground for the renegotiation of community dynamics and the definition of individual responsibilities in maintaining positive community dynamics.

Masculinities and men's role in community dynamics specifically ought to be unpacked and explored. Young men are commonly believed to be more likely to commit crimes in exchange for ransom. This can be analyzed as a simultaneous manifestation of male hegemony, individualism, and the absence of a social contract with the broader community. Young men are more likely to carry those attacks as they are expected to grow out of childhood and to become "men" by reaching some financial stability and acquiring authority and powerinfluence-over others. An exploitative crime such as kidnapping allows perpetrators to meet those three requirements: they gain authority by exerting power over someone assessed weaker in exchange of big sums of money and without requiring the consent of any parental figure. These criminal activities are also sponsored by a sheer sense of impunity stoked by a history of violence, ethnic sentiments, and loss of attachment to the state's polity.

Malleable young men trapped in a prolonged situation of scarcity-of economic resources, of natural resources for survival like food, of professional opportunities-and a sense of loss and apathetic relations to the state might be more likely to question their identity and relation to a 
community that have failed to provide for them at multiple levels. As such, in an environment where everything lacks and there is a sense of detachment and disenchantment with statelevel politics, violence is justified. Even more so, violence might provide them with potential ways to claim their manhood, which becomes celebrated and contributes to further othering and marginalizing groups that are considered adversarial.

Conversations to introduce some historical and sociological context around masculinities, gender expectations, individuals' wellbeing and communities' wellbeing would be helpful in naming and analyzing some conflicting interests that revolve around the creation of a shared identity. It is critical to use historical local references to present what manhood entailed pre colonization and how the rest of the community had also responsibilities in contributing to the community's wellbeing. These conversations should not aim to further normalize patriarchy and harmful expectations for young men. Instead, they should aim to provide other references that complement and/or challenge expectations that young men might put on themselves that might lead them to normalize their participation in criminal activities. Young men should be cultured into accepting that the capacity to withstand adversity and be successful is not tied to their manhood. They can become emotionally strong and successful by contributing to human progress and community wellbeing. Young men should grow up challenging religious and cultural precincts that tie their behavior to expressions of manhood in terms of gendered relationships and social obligations at home and in the society.

In renegotiating such a social contract involving young men, other actors in the community must be self-critical of their role as well. Participants raised concerns about the alleged complicity of elders and religious leaders who use provocative and coercive language to incite fear about the "other." Other concerns point to oppressive patriarchal influences at the grassroots where women play peripheral roles in the domestic and informal economy. It is at these levels that some of the women situated their peacebuilding roles. They insisted that the home is the foundation of peace. They described the home space as a formative environment for their children to imbibe and put into practice the community's codes of conducts hinged on respect and dignity of the human person.

While many of the traditional roles that women fill in the community have been undervalued by peace practitioners, the respect that they confer allows women the opportunity to persuade hardliners and young people to renounce violence. ${ }^{17}$ Peace practitioners would be well-served to recognize this influence in designing peace processes. In particular, they should ensure that women in these traditional roles are not only given a seat at the table but also afforded the opportunity to take lead roles in negotiation and managing community projects. Those conversations and reflections should fit as much as possible within traditional epistemologies of the area.

$\rightarrow(\mathrm{Re})$ visiting shared history. The fostering of shared identities would be incomplete without a new approach to history. It is critical for communities that seek to engage in peacebuilding to understand the legacy they have inherited and their potential to write a new narrative. This

17 For more on women's roles in armed groups and peacebuilding and their frequently overlooked and diminished contributions, see: Hilary Matfess, Brokers of Legitimacy: Women in Community-Based Armed Groups (Washington, D.C.: RESOLVE Network, 2020), https://doi.org/10.37805/cbags2020.1; Jakana Thomas, Duty and Defiance: Women in Community-based Armed Groups in West Africa (Washington, D.C.: RESOLVE Network, 2021), https://doi.org/10.37805/cbags2021.1. 
endeavor implies fully understanding how a conflict arose in the first place, which steps were taken to solve it (or not), and how learned lessons can inform future peacebuilding efforts. A way to do so would be to revisit school programs and make sure that curriculum centers on that history, as told and remembered by survivors, to foster dialogue and a premise for change. Conflicts could emerge if stories of the past are specifically chosen and mobilized for selfserving purposes. Students should be exposed to different accounts of their history in terms of the manifestations of good human relations as well as the violent history that hampered intercommunal relations in the past. Such an approach could foster a balanced appreciation of the evolution and development of the virtues and vices of their communities. Repairing any historical artefacts such as renaming monuments, spaces of encounter, or habits in a way that recognize that shared history could also be helpful in acknowledging the contribution of all actors and fostering reconciliation.

\section{Healing by co-building a legacy}

$\rightarrow$ Reimagining dialogue. Dialogue and mediation have been part of the peacebuilding repertoire of the different communities in Kaduna. Participants bemoaned the dormancy of these practices and noted that they had the potential to complement or challenge the state's judicial system if these local cultures of peace are resuscitated. Some of these practices entail paying compensation to farmers and herders for damages on crops and cattle routes, issuing warning to culprits, consoling victims of crime when reparations are unable to appease them, and, in extreme cases, banishing offenders through self-isolation measures. These peacemaking measures are managed at the community and family levels by elders, parents, and religious leaders. Participants believed that they could save face by adopting more reconciliatory processes rather than retributive or criminalizing stances at the expense of promoting healing in the community.

$\rightarrow$ Contested identities, survival, and shared resources. A central issue that links identity to survival and territorial belonging is the practice of animal husbandry. Participants from the numerous Southern Kaduna groups believed that the practice of migratory cattle breeding should be eclipsed by a more contemporary approach such as cattle ranching because of issues of cattle encroachments on farmlands and dispossession of ancestral land. For their part, the Fulani participants suggested the establishment and reconstruction of grazing reserve areas in places where the other communities have strong experiences of home life. This suggestion was based on both their understanding of the shared identity that they have with the other groups and their own sense of rootedness in the area.

Whatever the merits of both suggestions, the probable solution might be to negotiate a system in which ranches will be constructed during the rainy season in designated areas that are bought or allocated by each community for that purpose. This ranching system should be approached with the flexibility of allowing the animals to feed from crop residues during the dry season while providing organic manure to farmers. This option could preserve and improve the socio-economic symbiosis between the different groups and provide additional economic incentives and job opportunities for the beneficiaries.

There are difficult national dynamics involved in adopting these policies. The federal government seemed poised to recover the grazing routes that were gazetted in Nigeria in the 1960s. The 
reality is that most of the grazing routes have either been converted into homes or farmlands, replaced by urban infrastructures, or simply despoiled. Considering the connection that the people have with the land, there is a need for policymakers and peace practitioners to work with the communities to negotiate space and decide on how and where the ranches should be constructed. Peace practitioners and local communities could work together to construct such projects by utilizing the agency of groups who share a complementary relationship in the area. The project will serve as a means of employment and an opportunity to forge local ownership of the ranches, while guarding against vandalization or theft.

$\rightarrow$ Critical enablers for a meaningful dialogue. Establishing a community center can be a powerful platform for negotiating space through storytelling. A storytelling program is a way of "staying in touch" and passing on folklores of moral relevance to the younger generation. It may also provide the platform for cross-community engagement between the different adversarial groups in Kaduna. This activity could douse their combustible relationship in some quarters. Such stories could either be published into books or used as an online educational resource for people in segregated enclaves. Constructive storytelling can help to dispel destructive biases and demystify the "other." 18

Moreover, some participants within academia broached the importance of enlivening the indigenous languages of the people as a way of mediating positive encounters. They proposed that such languages should be included in the curriculum of secondary and tertiary institutions where members of the communities would serve as teachers. They also highlighted the important volunteering roles that people could play to teach these languages at the community centers.

Some participants considered their mastery of indigenous languages as critical to encouraging intermarriages between the different groups, which in turn would improve social cohesion and resilience to conflict. Yet, intermarriage also brings with it the potential to enflame violence when the celebrations of such unions are viewed as provocative, particularly if they entail either the forceful or willing conversion of women into Islam or Christianity. ${ }^{19}$

\section{Social media, local representation, and knowledge-brokering}

Social media sites such as Facebook and Twitter have been a veritable platform for the practice of activism. Through this medium and other physical platforms of activism some young people have facilitated the establishment of internally displaced camps and secured the release of kidnapped victims by way of peaceful protests and fundraising. The release on April 5, 2021, of 27 students kidnapped on March 11, 2021, from the Federal College of Forestry Mechanization in Afaka, Kaduna State, owed largely to the efforts of young people who raised funds and protested the near descent to anarchy in the state. Poignantly, some participants shared that the state has used its security forces to brutally attack some of these activists for their alleged subversive tendencies and incendiary speeches and write-ups. This anti-people approach could risk sowing seeds for internal rebellion.

18 Jessica Senehi, "Building Peace: Storytelling to Transform Conflicts Constructively," in Handbook of Conflict Analysis and ResoIution, eds. Dennis J. D. Sandole, Sean Byrne, Ingrid Sandole-Staroste, and Jessica Senehi (Abingdon, UK: Routledge, 2009), 201-214.

19 Kaduna Peace Committee Report 2015, obtained from the Justice, Development and Peace Commission of Kaduna Archdiocese on January 4, 2018. 
Donors and peacebuilders could set up and or work with existing news platforms in Kaduna such as the House of Justice Radio and other local radio and TV stations in the state to initiate a series of documentaries to showcase positive contact among the different ethno-religious groups in the state. Some of the everyday contact activities in the area include social and economic transactions in the informal markets, motor parks, on the streets, at weddings, anniversaries, and birthdays. Kate Meagher has observed positive encounters "between religiously mixed tailors and Muslim embroidery specialists," and motorcyclists or Okada men. ${ }^{20}$ These complementary experiences are also visible during conflicts when members of the different communities reach out to help those at risk of identity-motivated violence. Such selfless stories of sacrificial altruism are often overshadowed by stereotyped and inflamed narratives of acrimony spread in everyday conversations and on some news channels in Nigeria. This project can be accompanied by photography and arts to capture shared positive moments that could be published in the news media and archived on a website.

There is also an information deficit on the rampage of kidnapping in the state. There is no central repository of this crisis in terms of its frequency, hotspots, identity of perpetrators, and their modus operandi. The available data on violent deaths in Nigeria from the Nigeria Watch database describes perpetrators as "bandits," "kidnappers," "mob," revealing little about their identity, motives, and approaches. Everyday discourses in Nigeria simply describes perpetrators of such violence as "unknown gunmen." Local peacebuilders could link up with donors and other peace practitioners to fill this gap on dispersed reports about kidnapping. They can set up an information office and a website through which they could collate useful data, and leverage such information to engage the media and civil society to pressure the government to address the crisis by working with people at the grassroots level. This process could also serve to enlighten the public on security vigilance and crisis preparedness.

$\rightarrow$ Reimagining the state: Autonomous Local Governance. In Nigeria, all the Local Government Areas (LGAs) receive constitutionally mandated direct funding. This funding trickles down to the chiefdoms which are regarded by the state government in Kaduna as overbearing to the local government councils. Consequently, the government, which wields prodigious power to make unilateral decisions for the local constituencies, has reduced the number of district heads in the state and altered the nomenclature of the titles of some of the traditional chiefs and their chiefdoms. In particular, the name of "Gbagyi Chiefdom" in Chikun LGA of the state has been changed to "Chikun Chiefdom." ${ }^{11}$ This policy is ostensibly crucial in detribalizing and addressing the indigene-settler colonial legacy. However, the Southern Kaduna groups contended that such lopsided intervention based chiefly on financial considerations denigrates their cultural practices and likely aggravates ethnoreligious tensions rather than defuse them.

Decoupling the chieftaincy structures from the fiduciary and financial responsibilities of the LGAs and the state might be a way of decentralizing power and managing the distribution of state-level resources. If the reason for dissolving the district units in southern Kaduna is for

20 Kate Meagher, "Complementarity, Competition and Conflict: Informal Enterprise and Religious Conflict in Northern Nigeria," in Creed and Grievance: Muslim-Christian Relations and Conflict Resolution in Northern Nigeria, eds. Abdul Raufu Mustapha and David Ehrhardt (New York: James Currey, 2018), 189, https://doi.org/10.1017/9781787442375.

21 John Shiklam, "Kaduna Renames Gbagyi Chiefdom, Elevates Traditional Ruler," This Day, November 5, 2018, https://www. thisdaylive.com/index.php/2018/11/05/kaduna-renames-gbagyi-chiefdom-elevates-traditional-ruler/. 
the purposes of the local council to invest in "capital projects and deliver on public goods," 22 the chiefdoms could be organized in a way as to generate their own income by refocusing on agriculture and other vocational initiatives to transform their natural environments and maintain a modicum of autonomy. These chiefdoms could deliver on key services including resolving land-related conflicts through dialogue at community or peace centers and provide local security vigilance and vocational skills in tailoring, cobbling, and other entrepreneurial ventures. Local actors and peace practitioners can support these community development projects in a conflict sensitive manner through the provision of training and resources that are rooted in the traditional practices of the people.

This self-sustaining local governance model can provide the services that the state often ignores due to the ethno-religious dispositions of ruling politicians. The Kafanchan Peace Declaration underscored the "disparities in the delivery of social and public utility services particularly in areas of high polarization and recommended a huge change of culture by the State Government of Kaduna within its departments, agencies and public bodies to serve every community equally." ${ }^{23}$ Research and praxis in PACS must continue to interrogate how people can carve out spaces to complement and counteract some of the oppressive structures of the state.

\section{Conclusion}

This policy note has examined some of the everyday architecture of peace that may be useful for responding to violent conflicts and crime in Kaduna. Ordinary citizens in the state consider their spirituality, socio-economic relationships, and traditional practices of mediation and dialogue as the building blocks of sustaining peace. These tools could be leveraged by donor organizations and peacebuilding practitioners within and outside Nigeria to work with the people to establish peace hubs for constructive dialogue and storytelling on shared identity, history, and healthy masculinity. An information office and news channels for showcasing a series of documentaries on intergroup contact and other arts-based projects, including paintings and photography, were also identified as useful pathways of reconciliation that may dampen combative ethno-religious ties.

These intangible resources must be complemented by a conflict sensitive training on entrepreneurial ventures and primary healthcare, and the reconstruction of vandalized homes, schools, and places of worship. Enhancing the livelihood options of local actors, which involve "investment in electricity and transport, local business incentives and job creation as much as social welfare," ${ }^{24}$ will consolidate efforts at building security and mutual tolerance that will improve everyday socioeconomic precarity that interferes with peaceful relations among the different groups of Southern Kaduna. In the long run, such interventions could be decisive in fostering a community in Kaduna where, as Mahmood Mamdani argues, there will neither be permanent majority nor minority, neither settler nor native. ${ }^{25}$

22 Mohammed Lere, "In major restructuring, El-Rufai Slashes Kaduna Districts to Pre-2001 numbers," Premium Times, June 11, 2017, https://www.premiumtimesng.com/regional/nwest/233728-in-major-restructuring-el-rufai-slashes-kaduna-districtsto-pre-2001-numbers.html.

23 Kafanchan Peace Declaration, The Southern Kaduna State Inter-Communal Dialogue, March 23, 2016, https://www.peaceagreements.org/generateAgreementPDF/1922.

24 Meagher, "Complementarity, Competition and Conflict," 189.

25 Mamdani, Neither Settler nor Native. 


\section{Suggested further reading}

\section{On Issues of Belonging}

Adebanwi, Wale. "Terror, territoriality and the struggle for indigeneity and citizenship in Northern Nigeria." Citizenship Studies 13, no. 4 (2009): 349-363. https://doi.org/10.1080/13621020903011096.

Angerbrandt, Henrik. "Religion, ethnicity, and citizenship: Demands for territorial self-determination in Southern Kaduna, Nigeria." Journal of Contemporary African Studies 33, no. 2 (2015): 232-250. https://doi.org/10.1080/02589001.2015.1066081.

Anyaduba, Chigbo A. "Broadening the Canon: Africa and Its non-migrant diasporas." South-North Cultural and Media Studies 30, no. 4 (2016): 507-521. https://doi.org/10.1080/02560046.2016.1226728.

Bøås, Morten, and Kevin C. Dunn. Politics of origin in Africa: Autochthony, citizenship and conflict. London/New York: Zed Books, 2013.

Clarkson, Adrienne. Belonging: The Paradox of Citizenship. Toronto, ON: House of Anansi Press Inc., 2014.

\section{On Local Peacebuilding}

Autesserre, Séverine. "International peacebuilding and local success: Assumptions and effectiveness." International Studies Review 19, no. 1 (2017): 114-132. https://doi.org/10.1093/isr/viw054.

Björkdahl, Annika, and Stefanie Kappler. Peacebuilding and Spatial Transformation: Peace, Space and Place. Abingdon, Oxon: Routledge, 2017.

\section{On Intercommunal Conflicts}

Baba-Muhammad, T. A., and M.B. Tukur. "The state of grazing reserves and their potential capacity to absorb pastoralists." In Rural banditry and conflicts in Northern Nigeria, edited by K. J. Muhammad and J. Ibrahim, 189-216. Abuja: Centre for Democracy and Development, 2015.

Barkindo, Fr. Atta, Habiba Makanjuola, and Arthur Martins-Aginam. From the Valley of Death: Memory, healing and Inter-Group Dialogue in Southern Kaduna. Abuja: The Kukah Centre, 2017. http://thekukahcentre.org/wp-content/uploads/2018/11/ NSRP-Report.pdf.

Blench, Roger. Fulbe, Fulani and Fulfulde in Nigeria: Distribution and Identity. Nigerian National Livestock Resource Survey, Working Paper No. 23, 1994. http://www.rogerblench.info/Pastoralism/PastAf/Nigeria/FulBe\%20identity\%201990.pdf.

Bukari, Kaderi Noagah, and Nicholaus Schareika. "Stereotypes, prejudices and exclusion of Fulani pastoralists in Ghana." Pastoralism 5, no. 20 (2015): 1-12. https://doi.org/10.1186/s13570-015-0043-8.

Ducrotoy, M. J., W. R. Crawford, A. P. M. Shaw, U. B. Musa, W. J. Bertu, A. M. Gusi, R. A. Ocholi, A. O. Majekodunmi, and S. C Welburn. "Wealth, household heterogeneity and livelihood diversification of Fulani pastoralists in the Kachia Grazing Reserve, northern Nigeria, during a period of social transition." PLoS One 12, no. 3 (2017): e0172866. https://doi.org/10.1371/journal. pone.0172866.

Eke, Surulola. "Nomad Savage and Herder-Farmer conflicts in Nigeria: the (un)making of an Ancient Myth." Third World Quarterly 41, no. 5 (2019): 745-763. https://doi.org/10.1080/01436597.2019.1702459.

Mustapha, Abdul Raufu, and David Ehrhardt. Creed and Grievance: Muslim-Christian Relations and Conflict Resolution in Northern Nigeria. New York: James Currey, 2018. https://doi.org/10.1017/9781787442375. 


\section{Bibliography}

Björkdahl, Annika, and Stefanie Kappler. Peacebuilding and Spatial Transformation: Peace, Space, Peace. Abingdon, Oxon: Routledge, 2017.

Byrne, Sean, Mary Anne Clarke, and Aziz Rahman. "Colonialism and Peace and Conflict Studies," Peace and Conflict Studies 25, no. 1 (2018): Article 1, https://doi.org/10.46743/1082-7307/2018.1432.

Firchow, Pamina. Reclaiming Everyday Peace: Local Voices in Measurement and Evaluation after War. Cambridge: Cambridge University Press, 2018.

Guttschuss, Eric. 'Leave Everything to God.' Accountability for Intercommunal Violence in Plateau and Kaduna States, Nigeria. USA: Human Rights Watch, 2013. https://reliefweb.int/sites/reliefweb.int/files/resources/nigeria1213 ForUpload.pdf.

John, Philip Hayab. "Narratives of identity and sociocultural worldview in song texts of the Ham of Nigeria: A discourse analysis investigation." PhD dissertation, Stellenbosch University, 2017. http://scholar.sun.ac.za/handle/10019.1/100914.

Mac Ginty, Roger. International Peacebuilding and Local Resistance: Hybrid Forms of Peace. New York: Palgrave Macmillan, 2011.

Kafanchan Peace Declaration. The Southern Kaduna State Inter-Communal Dialogue, 2016. https://www.peaceagreements.org/ generateAgreementPDF/1922.

Kaduna Peace Committee Report 2015. Justice, Development and Peace Commission of Kaduna Archdiocese.

Lere, Mohammed. "In major restructuring, El-Rufai Slashes Kaduna Districts to Pre-2001 numbers." Premium Times, June 11, 2017. https://www.premiumtimesng.com/regional/nwest/233728-in-major-restructuring-el-rufai-slashes-kaduna-districtsto-pre-2001-numbers.html.

Maiangwa, Benjamin. The Crisis of Belonging and Ethnographies of Peacebuilding in Kaduna State, Nigeria. Lanham: Lexington Books, 2020

Mamdani, Mahmood. Neither Settler nor Native: The Making and Unmaking of Permanent Minorities. Cambridge, MA: Belknap Press, 2020.

Matfess, Hilary. Brokers of Legitimacy: Women in Community-Based Armed Groups. Washington, D.C.: RESOLVE Network, 2020. https://doi.org/10.37805/cbags2020.1.

Meagher, Kate. "Complementarity, Competition and Conflict: Informal Enterprise and Religious Conflict in Northern Nigeria." In Creed and Grievance: Muslim-Christian Relations and Conflict Resolution in Northern Nigeria, edited by Abdul Raufu Mustapha and David Ehrhardt, 184-222. New York: James Currey, 2018. https://doi.org/10.1017/9781787442375.

Mustapha, Abdul Raufu. "Introduction: Religious encounters in northern Nigeria." In Creed and Grievance: Muslim-Christian Relations and Conflict Resolution in Northern Nigeria, edited by Abdul Raufu Mustapha and David Ehrhardt, 1-34. New York: James Currey, 2018. https://doi.org/10.1017/9781787442375.

Ochonu, Moses. Colonialism by Proxy: Hausa Imperial Agents and Middle Belt Consciousness in Nigeria. Indiana: University of Indiana Press, 2014.

Shiklam, John. "Kaduna Renames Gbagyi Chiefdom, Elevates Traditional Ruler." This Day, November 5, 2018. https://www.thisdaylive.com/index.php/2018/11/05/kaduna-renames-gbagyi-chiefdom-elevates-traditional-ruler/.

Senehi, Jessica. "Building Peace: Storytelling to Transform Conflicts Constructively." In Handbook of Conflict Analysis and Resolution, edited by Dennis J. D. Sandole, Sean Byrne, Ingrid Sandole-Staroste, and Jessica Senehi, 201-214. Abingdon, UK: Routledge, 2009.

Thomas, Jakana. Duty and Defiance: Women in Community-based Armed Groups in West Africa. Washington, D.C.: RESOLVE Network, 2021. https://doi.org/10.37805/cbags2021.1.

Walker, Andrew. "Eat the heart of the infidel": The harrowing of Nigeria and the rise of Boko Haram. London: Hurst \& Company, 2016. 


\section{About the Note}

\section{Author: Benjamin Maiangwa}

Benjamin Maiangwa is an Assistant Professor in the Department of Political Science at Lakehead University. His research centers on politics, culture, and ideas of belonging in the postcolony. The author would like to thank Brandon Kendhammer for constructive feedback on an early draft, and Christiane Essombe for sharing ideas on identity and masculinity.

The views expressed in this publication are those of the authors. They do not necessarily reflect the views of the RESOLVE Network, the U.S. Institute of Peace, or any entity of the U.S. government.

\section{RESOLVE NETWORK}

better research.informed practice.improved policy on violent extremism. 